NBER WORKING PAPER SERIES

THE EURO AND EUROPEAN ECONOMIC CONDITIONS

\author{
Martin S. Feldstein \\ Working Paper 17617 \\ http://www.nber.org/papers/w17617 \\ NATIONAL BUREAU OF ECONOMIC RESEARCH \\ 1050 Massachusetts Avenue \\ Cambridge, MA 02138 \\ November 2011
}

The views expressed herein are those of the author and do not necessarily reflect the views of the National Bureau of Economic Research.

NBER working papers are circulated for discussion and comment purposes. They have not been peerreviewed or been subject to the review by the NBER Board of Directors that accompanies official NBER publications.

(C) 2011 by Martin S. Feldstein. All rights reserved. Short sections of text, not to exceed two paragraphs, may be quoted without explicit permission provided that full credit, including $(\mathbb{C}$ notice, is given to the source. 
The Euro and European Economic Conditions

Martin S. Feldstein

NBER Working Paper No. 17617

November 2011

JEL No. E0

\begin{abstract}
$\underline{\text { ABSTRACT }}$
The creation of the euro should now be recognized as an experiment that has led to the sovereign debt crisis in several countries, the fragile condition of major European banks, the high levels of unemployment, and the large trade deficits that now exist in most Eurozone countries. Although the European Central Bank managed the euro in a way that achieved a low rate of inflation, other countries both in Europe and elsewhere have also had a decade of low inflation without incurring the costs of a monetary union.

The emergence of these problems just a dozen years after the start of the euro in 1999 was not an accident or the result of bureaucratic mismanagement but the inevitable consequence of imposing a single currency on a very heterogeneous group of countries, a heterogeneity that includes not only economic structures but also fiscal traditions and social attitudes.

This paper reviews (1) the reasons for these economic problems, (2) the political origins of the European Monetary Union, (3) the current attempts to solve the sovereign debt problem, (4) the long-term problem of inter-country differences of productivity growth and competitiveness, (5) the special problems of Greece and Italy, (6) and the pros and cons of a Greek departure from the Eurozone.
\end{abstract}

Martin S. Feldstein

President Emeritus

NBER

1050 Massachusetts Avenue

Cambridge, MA 02138-5398

and NBER

msfeldst@nber.org 


\section{The Euro and European Economic Performance}

\section{Martin Feldstein}

The creation of the euro should now be recognized as an experiment that has had a number of substantial economic costs. The emergence of sovereign debt crises just a dozen years after its creation in 1999 was not an accident or the result of bureaucratic mismanagement but the inevitable consequence of imposing a single currency on a very heterogeneous group of countries, a heterogeneity that includes not only economic structures but also fiscal traditions and social attitudes.

Among the economic consequences of the euro are the sovereign debt crisis in several countries, the fragile condition of major European banks, the high levels of unemployment, and the large trade deficits that now exist in most Eurozone countries. Although the European Central Bank managed the euro in a way that achieved a low rate of inflation, other countries both in Europe and elsewhere have also had a decade of low inflation without incurring the costs of a monetary union.

The political goal of creating a harmonious Europe that inspired the early advocates of a European union has not been achieved. Germany and France have dictated painful conditions in Greece and Italy as a condition for financial help while the leaders of Germany and France clashed with each other over the proper role of the European Central Bank and over how the burden of financial assistance will be divided.

The initial impetus that led to the European Monetary Union and the euro was actually political rather than economic. Political leaders generally favored the creation of the euro as a step toward deeper political integration. They reasoned that the use of a common currency would create in the public a greater sense of belonging to a European community while the shift of responsibility for monetary policy from national capitals to a single European Central Bank in Frankfurt would signal a shift of political power.

There were many different reasons for the pursuit of political integration. French political leaders Jean Monet and Robert Schuman articulated the idea of European integration soon after World War II 
with the stated goal of preventing another European war, a theme later echoed by German Chancellor Helmut Kohl when he said the European union was needed to "contain Germany within Europe." French officials may also have seen European integration as a way of increasing France's role within Europe and on the global stage. In contrast, German political leaders may have seen Germany as the natural leader of an integrated Europe, since Germany has the largest economy and is located in the center of an expanded western Europe. As Chancellor Kohl told his people, with some ambiguity, "Germany is your fatherland, Europe is your future."

Other countries were also eager for national reasons to join the euro currency at its beginning. Spain, which had only recently shifted from the Franco dictatorship and joined NATO, wanted to be recognized as a fully legitimate member of Europe. Italy, where the European community began with the Treaty of Rome, insisted on being admitted despite it enormous fiscal debt in order to avoid a loss of face. Since France was eager to have these countries join, the admission standard of a budget deficit below 3 percent of GDP and a national debt below 60 percent of GDP was adjusted to admit countries that were deemed to be "making progress" toward the deficit and debt standards even if they were far away from actually reaching those goals.

But the primary political motive for increased European integration may have been, and may still be, to enhance Europe's role in world affairs. In 1956, the United States forced Britain and France to withdraw from the Suez Canal by threatening to sell British government bonds and by blocking the IMF assistance that Britain then needed. In a reaction to that humiliating withdrawal, Chancellor Conrad Adenauer of Germany told a leading French politician, "France and England will never be powers comparable to the United States and the Soviet Union. Nor Germany either. There remains to them only one way of playing a decisive role in the world; that is to unite to make Europe. ... We have no time to waste. Europe will be your revenge."

That was just one year before the Treaty of Rome launched the Common Market in 1957. That sentiment may explain why many European politicians argue that the euro must be preserved at all cost because, as Chancellor Angela Merkel recently said, "If the euro fails, Europe fails." 
The Common Market developed into the European Economic Community in 1967 and the European Union in the Maastricht treaty of 1992, creating not only a larger free trade area but also providing for the mobility of labor and other aspects of an integrated European market for goods and services. That was then used as a stepping stone toward a greater political union with the publication of a report by the European Commission, written by the former French finance minister Jacques Delors and titled "One Market, One Money," which made the specious argument that the free trade area could only succeed if there were a single currency for the member countries.

There is of course nothing in economic logic or experience that implies that free trade requires a single currency. The North American Free Trade Area has stimulated increased trade without anyone thinking that the United States, Canada and Mexico would have a single currency. Japan has succeeded as a major global exporter despite substantial fluctuations in the value of its currency. We now see that the European Union has achieved a free trade market even though only 17 of its 27 members use the euro.

But the political process evolved through the Maastricht Treaty's creation of the European Monetary Union and the plans for the single currency which eventually began in 1999. Germany resisted this move to the single currency, reluctant to give up the Deutschemark which had brought price stability and prosperity to postwar Germany. German officials argued that the monetary union should not begin until it could be part of a political union. Since there was no support at that time for a leap to an ill-defined political union, the German position seemed to many to be only a way to postpone or prevent the move to a single currency.

But France and others succeeded in establishing a schedule in the Maastricht treaty leading to the single currency in 1999. Germany was only able to shape the Maastricht treaty in a way that gave German characteristics to the European Central Bank (ECB), including formal independence of the ECB, a single policy goal of price stability, a prohibition on purchasing bonds from member governments, a "no 
bailout" rule for countries that became insolvent, and a location in Frankfurt.

Germany also forced the creation in 1997 of a "stability" agreement (labeled, at French insistence, as the Stability and Growth Pact) that established financial penalties for any country that had a budget deficit of more than 3 percent of its GDP or a debt that exceeded 60 percent of its GDP. When France and Germany soon violated these conditions, the European Council voted not to impose penalties and the terms of the Pact were weakened so that they became meaningless.

\section{Economist Warnings}

Long before the euro became official in 1999, economists pointed to the potential effects that a single currency would have on the economies of Europe. (e.g., Martin Feldstein, "The Case Against the Euro", The Economist, 1992; "EMU and International Conflict", Foreign Affairs, 1997)

A single currency means that all of the countries in the monetary union have the same monetary policy and the same basic interest rate, with interest rates differing among borrowers only because of perceived differences in credit risk. A single currency also means a fixed exchange rate within the monetary union and the same exchange rate relative to all other currencies even when individual countries in the monetary union would benefit from changes in relative values.

Economists explained that the result would be greater fluctuations in output and employment, a much slower adjustment to declines in aggregate demand, and persistent trade imbalances with the rest of the world. We have seen all of this occur in recent years.

Here's why. When a county has its own monetary policy, it can respond to a decline in demand by lowering interest rates to stimulate economic activity. But the European Central Bank must make monetary policy based on the overall condition of all the countries in the monetary union. This means interest rates that are too high for those countries with rising unemployment and too low in other countries where wages are rising too rapidly. Because of the size of the German economy, the 
ECB monetary policy must give German conditions greater weight in its decisions than the conditions in other countries.

A country with its own currency can also allow the value of the currency to respond to changes in foreign demand and domestic conditions. For example, if Spain had continued to have the peseta instead of the euro, a fall in foreign demand for Spanish exports would cause the value of the peseta to fall, thereby making Spanish goods more competitive, leading to increased demand for those products and causing Spanish consumers to substitute domestic goods and services for imports. Similarly, if productivity in Spain lagged behind that of other countries, market pressures would cause the peseta to decline rather than leading to a growing trade deficit as it does with the current fixed exchange rate.

The shift to a monetary union and the tough anti-inflationary policy of the European Central Bank caused interest rates to fall in countries like Spain and Italy where expectations of high inflation had previously kept interest rates high. Households and governments in those countries responded to the low interest rates by increasing their borrowing, with households using the increased debt to finance a surge in home building and house prices while governments borrowed to finance budget deficits that accompanied larger social transfer programs.

The result was rapidly rising ratios of public and private debt to GDP in several countries, including Italy, Greece, Spain and Ireland. Despite the increased risk to lenders that this implied, the global capital markets did not respond by raising interest rates on countries with rapidly rising debt levels. Until recently, bond buyers assumed that a bond issued by any government in the European Monetary Union was equally safe, basically ignoring the "no bailout" provision of the Maastricht treaty. As a result, the interest rates on Greek and Italian government bonds differed from the interest rate on German government bonds by only a small fraction of one percent.

Before the EMU, large fiscal deficits generally led to higher interest rates or declining exchange rates. These market signals acted as an automatic warning to those countries to reduce their borrowing. The monetary union eliminated those market signals and the higher cost of funds that would otherwise have limited household borrowing. The result was that 
countries borrowed too much and banks loaned too much on overpriced housing.

When the markets eventually recognized the error of regarding all EMU countries as equally safe, interest rates rose rapidly on the sovereign debts of Greece, Italy and Spain. Market dynamics started a selfreinforcing process by which rising interest rates led to the risk of insolvency and of eventual default. More specifically, the fear that Greece might have trouble meeting its debt payments caused the interest rate on Greek debt to rise and the expectation of higher future interest payments implied an even larger future debt burden. What started as a concern about a Greek liquidity problem - i.e., about the ability of Greece to have the cash to meet its next interest payments became a solvency problem, a fear that Greece would never be able to repay its existing and accumulating debt. That pushed interest rates even higher and led eventually to a negotiated partial default in which holders of Greek sovereign debt were forced to accept a 50 percent write down in the value of their bonds. The Greek experience raised the perceived riskiness of Italian government debt, causing the interest rate on Italian government bonds to rise from less than four percent to more than seven percent, pushing Italy to the brink of insolvency.

A different market dynamic affected the relation between the commercial banks and the European governments. Since the banks were heavily invested in government bonds, the declining value of those bonds hurt the banks. The banks then turned to the government to protect depositors and other creditors, thus magnifying the original problem. In Ireland and Spain, the problem began with mortgage defaults, hurting the banks and leading to government guarantees, thus adding to the government debt. And since the banks were also heavily invested in government bonds, the weakness of the Spanish and Irish government debt further hurt the banks.

\section{Europe is Not the United States}

The political leaders in the 1990s before the move to the euro generally ignored the warnings of economists because they were focused on what they saw as the bigger political goal of European integration. Those who even listened to the economists dismissed the warnings by arguing 
that the United States is also a large continent of heterogeneous states but functions successfully with a single currency. This argument failed to recognize three important differences between the United States and Europe.

First, the United States is effectively a single labor market in which workers move from areas of high and rising unemployment to places where jobs are more plentiful. In Europe, national labor markets are effectively separated by barriers of language, culture, religion, union membership, and national social insurance systems. While some workers do migrate within Europe, there is nothing like the degree of mobility seen in the United States.

A second important difference is that the United States has a centralized fiscal system in which individuals and businesses pay the majority of their taxes to Washington. When economic activity in a state slows relative to the rest of the nation, the taxes paid by individuals and businesses in that state to Washington decline and the funds received in that state from Washington for unemployment benefits and other transfer programs increase. Roughly speaking, each dollar of GDP decline in a state like Massachusetts or Ohio triggers changes in taxes and transfers that offset about 40 cents of the local decline in GDP.

There is no comparable offset in Europe where taxes are almost exclusively paid to and transfers received from the individual national governments. The Maastricht treaty specifically reserves this tax and transfer authority to the national governments, a reflection of the fact that Europeans are not willing to transfer funds to the people of other countries in the way that Americans are willing to do among the people of different states.

The third important difference is that each state in the United States is restricted by its state constitution to balance its annual operating budget. While "rainy day" funds are used to deal with temporary revenue shortfalls, general obligation borrowing is limited to capital projects like roads and schools. Even a state like California, seen by many as the poster child of fiscal profligacy, now has an annual budget deficit of just one percent of the state gross domestic product and a general obligation debt of just four percent. These state deficit limits are 
seen as the natural implication of the fact that U.S. states cannot create money to finance fiscal deficits. They prevent the kind of deficit and debt problems that have come to occur in the Eurozone where capital markets ignored the lack of monetary independence and regarded individual nations as capable of running large deficits.

\section{Solving the Sovereign Debt Problem}

By the fall of 2011, several European countries had debt to GDP ratios that made default a serious possibility. Sharp write-downs in the value of their sovereign debt would do substantial damage to the European banks and possibly to banks and other financial institutions in the United States.

Three distinct strategies are being proposed to deal with this situation. In the first of these, the Eurozone leaders agreed in October 2011 that the banks should increase their capital ratios and that the European Financial Stability Facility (EFSF) should be expanded from 400 billion euros to more than a trillion euros to provide insurance guarantees that would allow Italy and potentially Spain to access the capital markets at reasonable interest rates.

This plan to increase the banks' capital won't work because the banks don't want to dilute current shareholders by seeking either private or public capital. Instead, they are reducing their lending, particularly to borrowers in other countries, causing a further slowdown in European economic activity. It is also not clear how the EFSF can borrow the additional funds since doing so is opposed by Germany, the largest potential guarantor of that debt. Moreover, even a trillion euros would not give the EFSF enough funds to provide effective guarantees to potential buyers of Italian and Spanish debt if those countries might otherwise appear insolvent.

The second strategy calls for the European Central Bank to buy the bonds of Italy, Spain and other high debt to keep their interest rates low. The ECB has already been doing that to a limited extent but not enough to stop Greek and Italian rates from reaching unsustainable levels. Asking the ECB to expand this policy would directly contradict the "no bailout" terms of the Maastricht treaty. Germany very much opposes 
this and two German members of the ECB Board (Axel Weber, who was expected to become the President of the ECB, and Juergen Stark) resigned over this issue.

The third strategy is favored by those who want to use this crisis to advance the development of a political union. They call initially for a "transfer union" or a fiscal union in which those countries with budget surpluses would transfer funds each year to the countries running budget deficits and trade deficits.

In exchange for these fiscal transfers, the EMU would be given the authority to review budgets and insist on changes in the policies of recipient countries aimed at reducing their fiscal deficits, increasing their growth, and raising their international competitiveness. This has already been done with Greece and Italy.

The case of Greece has been the most dramatic. By October of 2011, Greece was unable to borrow in the global capital market and therefore had to depend on credit extended by the ECB and the International Monetary Fund to pay civil servants and to make social transfers. Chancellor Merkel of Germany and President Sarkozy of France summoned the Greek Prime Minister and told him that he must abandon his plan for a referendum on the budget plan and must persuade the Greek parliament to accept their plan to reduce the Greek budget deficit or be forced out of the euro. The prime minister agreed and returned to force that legislation through the Greek parliament. He then resigned and a temporary technocrat prime minister, Lucas Papademos, was appointed with responsibility for implementing the budget cuts designed in Brussels.

Parliamentary defections and public riots indicate how much the Greek people resent being forced by Germany to change their economic behavior, to accept layoffs of government employees who thought they had lifetime jobs, and to contract demand at a time of double digit unemployment and rapidly falling GDP. At the same time, many voters in Germany resent making transfers to the Greeks and seeing the rules of the ECB being radically changed. 
The current situation in Italy is different because Italy is not yet dependent on explicit transfers from the European Union or the IMF. But Italy does depend on the support of the ECB to limit the rise in the interest rate on its government bonds. Germany and France pressured Italy to adopt new policies, leading to the resignation of prime minister Berlusconi and the appointment of a technocrat committed to resolving the Italian fiscal problems.

The creation of the euro has thus created tensions and conflicts within Europe that would not otherwise have existed. Although these conflicts are being resolved by the exercise of economic and financial power rather than by military interventions, the sovereign governments of Greece and Italy are being forced to accept the policies imposed by Germany and France. Further steps toward a permanent transfer union or fiscal union will only exacerbate these tensions and conflicts.

\section{$\underline{\text { Greece and Italy }}$}

The Greek budget deficit of 9 percent of GDP is too large to avoid a further outright default on its national debt. With a current debt to GDP ratio of 150 percent and the current value of Greece's GDP falling in nominal euro terms at 4 percent, the debt ratio would rise in the next 12 months to 170 percent of GDP. Rolling over the debt as it comes due and paying higher interest rates on such debt would raise the total debt even more quickly.

Even if a 50 percent partial default on the entire Greek national debt were to cut the existing interest payments in half, the deficit would still be six percent of Greece's GDP and the debt to GDP ratio would rise to 165 percent of GDP at the end of 12 months. And that excludes the adverse effect of the debt default on the Greek banks, forcing the Greek government to provide payments to Greek depositors which would further increase the national debt.

To achieve a sustainable path Greece must start reducing the ratio of national debt to GDP. This is virtually impossible as long as Greece's real GDP is declining. The basic budget arithmetic implies that even if Greece's real GDP starts growing at 2 percent (up from the current 7 percent real rate of decline) and inflation is at the ECB target of 2 
percent, the deficit must still not exceed six percent of GDP if the debt ratio is to stop increasing. Since the interest on the debt is now about 6 percent of GDP, the rest of the Greek budget must be brought into balance from its current three percent deficit.

Cutting the interest bill in half by a 50 percent default while balancing the rest of the budget would only reduce the deficit very slowly, from 150 percent now to 145 percent after a year, even if no payments to bank depositors and other creditors were required. It is not clear that financial markets will wait while Greece walks along this fiscal tightrope to a sustainable debt ratio well below 100 percent.

The situation in Italy is much better. Italy already has a primary budget surplus with tax revenue exceeding non-interest government outlays by about one percent of GDP and a slightly positive rate of growth. With interest on the national debt now equal to about 5 percent of GDP, Italy's total budget deficit is about four percent of GDP. A two percent of GDP reduction of that deficit would be enough to start a decline in the ratio of debt to GDP. That should not be difficult to achieve since Italian government spending is roughly 50 percent of GDP. There is a precedent for reducing the extremely generous public pensions that could provide a major part of the needed fiscal improvement. The prospect of a declining budget deficit has already reduced the interest rate on new government borrowing from 7.5 percent to 6.5 percent. Eliminating the budget deficit and starting to shrink the debt ratio more rapidly could bring the interest rate back to the four percent level that prevailed before the crisis began.

\section{Long Term Competitiveness}

Reducing the problem of large budget deficits and the related problem of the commercial banks that have invested in government bonds would still not solve the long-term competitiveness problem caused by monetary union. That more fundamental problem is the difference among EMU members in long-term competitiveness trends and the resulting differences in trade balances.

In the past year, Germany had a trade surplus of nearly $\$ 200$ billion dollar while the other members of the euro area had trade deficits 
totaling some $\$ 200$ billion. The more comprehensive measure that includes net investment income shows Germany with a current account surplus of 5 percent of its GDP while Greece has a current account deficit of nearly 10 percent of its GDP. That implies that Germany can invest in the rest of the world an amount equal to five percent of its GDP while Greece must borrow an amount equal to nearly 10 percent of its GDP to pay for its current level of imports. Italy and Spain had current account deficits in the past year of 3.7 percent of their GDP while France had a current account deficit of 2.5 percent of its GDP.

If Greece were not part of the Eurozone, its exchange rate with the rest of the world would adjust over time to prevent this type of large and growing trade deficit. More specifically, the need to finance that trade deficit would cause the value of the Greek currency to decline, making Greek exports more attractive to foreign buyers and encouraging Greek consumers to substitute Greek goods and services for imports. The rising cost of imports would also reduce real personal incomes in Greece, leading to less consumer spending and freeing up Greek output to be exported to foreign buyers.

But since Greece is part of the Eurozone, this automatic adjustment mechanism is missing. Greece's persistent and cumulative problem therefore arises because Greek productivity (i.e., output per employee) increases more slowly than that of Germany. If output per employee increases at three percent a year in Germany, real wages in Germany can also grow at three percent. If the ECB keeps inflation in the Eurozone at about two percent, German nominal money wages can rise at five percent a year. If Greek wages also rise at five percent a year while productivity in Greece grows at only one percent a year, the prices of Greek goods and services will increase two percent faster than the prices of German products. That increase in the relative price of Greek goods and services causes Greek imports to rise more rapidly and its exports to stagnate, creating an increasingly large Greek trade deficit.

This problem could be avoided if the annual rise in Greek wages were limited to two percent less than the rise in German wages. This may of course be politically difficult in the highly unionized Greek economy. It was essentially impossible during the past decade in which German wages grew at only about two percent a year, implying that Greek wages 
could not rise at all if Greece wanted to remain its relative competitiveness.

But limiting the future growth of Greek wages only deals with further deterioration of Greek competitiveness in the future. Stopping a further decline in Greek competitiveness would not correct the existing annual current account deficit of nearly ten percent of Greek GDP that Greece must somehow finance. To eliminate the existing current account deficit would require making Greek prices much more competitive than they are today by reducing the cost of producing Greek goods and services by about 40 percent relative to the cost in the rest of the Eurozone. Since that is not likely to be achieved by increased productivity, it must be achieved by lowering real wages relative to the real wages of Germany and others in the Eurozone.

That would at best be a very painful process, achieved by years and years of high unemployment and declining incomes. Greece now has an official unemployment rate of 16 percent and its real GDP is falling at a 7 percent annual rate. Continuing that poor performance for a decade or more is virtually unthinkable in a democracy.

Moreover, since that process would shrink the current account deficit only over a long period of time, Greece would need to continue borrowing to finance its current account imbalance. Even if Germany were willing to formalize such long term financial assistance by establishing a "transfer union" to provide those funds to Greece and others with large current account deficits, the controls that they would demand to keep wages and incomes declining would create severe political tensions.

\section{Leaving the Euro}

The alternative is for Greece to leave the Eurozone and return to its own currency. Although there is no provision in the Maastricht treaty for a country to leave, political leaders in Greece and other countries are no doubt considering that possibility for Greece. While Greece is currently receiving transfers from the other Eurozone countries, it is paying a very high price in terms of unemployment and social unrest for those transfers. Leaving now and creating a New Drachma would permit a 
devaluation and default that might involve much less economic pain than the current course. That "devaluation and default" strategy has been the standard response of countries in Asia and Latin America that had unsustainably large fiscal and trade deficits and that were able to devalue because they were not part of a monetary union.

Germany is now prepared to pay to try to keep Greece from leaving the euro because it fears that a Greek defection could lead to a breakup of the entire Eurozone, eliminating the fixed exchange rate that now benefits German exporters and the German economy more generally. If Greece leaves and devalues, the global capital market might assume that Italy would consider a similar strategy of "devalue and default." The resulting rise in the interest rate on its debt might then drive it to do so. If Italy reverts to a "New Lira" and devalues relative to other currencies, the competitive pressure might force France to devalue as well. At that point, the Eurozone would collapse.

But while Germany is now prepared to subsidize Greece and other countries to sustain the euro, Greece and others might nevertheless decide to leave if the conditions imposed by Germany are deemed to be too painful to accept.

Here's how that might work. Although Greece cannot create the euros that it now needs to pay civil servants and make transfer payments, the Greek government could start creating "New Drachmas" and declare that all contracts under Greek law, including salaries and shop prices, would be payable in New Drachmas. Similarly, all bank deposits and bank loans would be payable in these New Drachmas instead of euros.

The value of the New Drachma would fall relative to the euro, automatically reducing real wages and increasing Greek competiveness without going through a long and painful period of high unemployment. Instead, the lower value of the Greek currency would stimulate exports and a shift from imports to domestic goods and services. This would boost Greek GDP growth and Greek employment.

There would of course also be serious problems in making the transition to the New Drachma. Since the Maastricht treaty provides no way for a member of the Eurozone to leave, there is the risk that the 
other EMU members would require Greece to leave the European Union and therefore to forego the free trade and labor mobility benefits of the EU. They might do so to discourage Italy and others from using a similar exit strategy. But that "punishment" might not be sought by the other EU members, especially since ten of the 27 EU countries do not use the euro, and the Greek situation is clearly more desperate than that of Italy or Spain.

The primary practical problem of leaving the euro is that some Greek businesses and individuals have borrowed in euros from banks outside Greece. Since those loans are not covered by Greek law, the Greek government cannot change the obligation from euros to New Drachmas. The decline in the New Drachma relative to the euro would make it much more expensive for the Greek debtors to repay those loans. If the loans were fully enforced in euros, there could be widespread bankruptcies of Greek individuals and businesses, with second round effects on Greek banks to which those individuals and businesses have other debts. However, the experience after Argentina ended its link to the dollar in 2002 suggests that domestic Greek debtors would end up paying only a small fraction of the euro equivalent debts. The option to leave the EMU must therefore be very tempting.

\section{Final Thoughts}

Some of the countries that adopted the euro in 1999 would clearly have lower unemployment, a smaller national debt, a more competitive international position, and better prospects for the future if they had never been part of the European Monetary Union. The political relations within Europe would be less confrontational.

But breaking up the Monetary Union would be difficult and costly. Unfortunately, that potential cost was not considered when the European political leaders decided to adopt the single currency.

END

November 14, 2011 